\title{
PENGARUH IKLIM ORGANISASI DAN GAYA KEPEMIMPINAN TERHADAP KINERJA PEGAWAI
}

\author{
Ramnah \\ E-mail: ramnah@gmail.com \\ Muhammad Harlie \\ Sulastini \\ Universitas Islam Kalimantan (UNISKA) MAB Banjarmasin
}

\begin{abstract}
Government organizational human resources consisting of leaders and employees. Organization of youth sports culture and tourism is particular agencies a government that has personnel were 60 employees. Organization of youth sports culture and tourism of a system of the indonesian government is a system of government bureaucracy that was overall would be a lot determined by the these agencies.Research aims to understand effects of climate organizations and style leadership of the performance of employees. The kind of research this is research quantitative to test the influence of between variables free variable bound, with the number of respondents about 60 personnel.Research this analyzed by the use of a test statistic spss for windows version 17. The research results show that there are influence in partial between climate organizations and style leadership of the performance of employees. There is the influence of simultaneously between climate organization style leadership of performance.
\end{abstract}

Keywords : organizational climate, leadership style and performance 


\section{PENDAHULUAN}

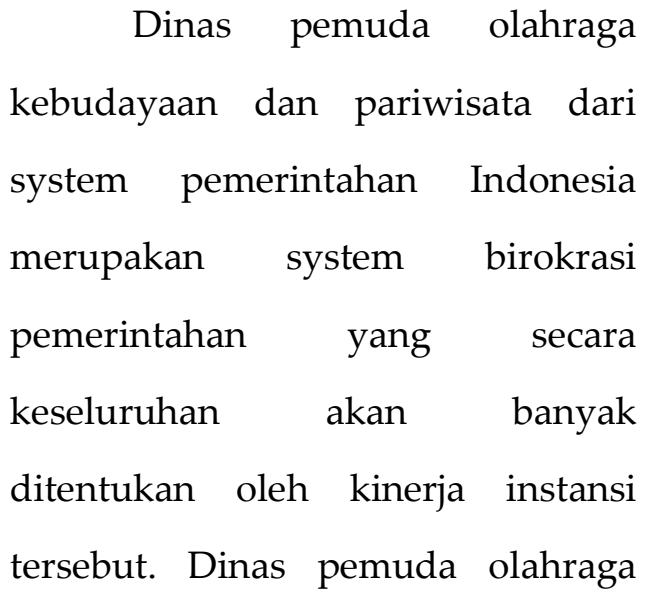

kebudayaan dan pariwisata

merupakan sebagai instansi

pelayanan public yang dituntut

untuk memperbaiki dan senantiasa

melakukan reformasi serta

mengantisipasi

perkembangan.Dalam rangka

meningkatkan citra kinerja dan

kinerja instansi pemerintah menuju

kearah professionalism dan

menunjang terciptanya

pemerintahan yang baik (good

govermance ) perlu adanya

penyatuan arah dan pandangan bagi

segenap jajaran pegawai

pemerintahan yang dapat

dipergunakan sebagai pedoman

atau acuan dalam melaksanakan

tugas dengan baik manejerial

maupun operasional di seluruh bidang tugas dan unit organisasi instansi pemerintah secara terpadu .

Faktor yang penting yang menentukan kinerja pegawai dan kemampuan organisasi beradaptasi dengan perubahan lingkungan menurut Bass et al .(2003), Locander et al. (2002), serta Yammarino et al. (1993) adalah kepemimpinan (leadership). Menurut Kerlinger dan padhazur (2002) faktor kepemimpinan mempunyai peran yang sangat penting dalam meningkatkan kinerja pegawai karena kepemimpinan yang efektif memberikan pengarahan terhadap usaha-usaha semua pekerja dalam mencapai tujuan- tujuan organisasi. Gaya kepemimpinan yang efektif dibutuhkan pemimpin untuk dapat meningkatkan kinerja semua pegawai dalam mencapai tujuan organisasi sebagai instansi pelayanan publik. Dengan demikian gaya kepemimpinan dapat menjadi pedoman yang baik dalam peningkatan kinerja pegawai. Kinerja yang baik akan diperoleh bila karyawan mempunyai loyalitas 
terhadap perusahaan, untuk mencapai hal tersebut maka perlu didukung oleh kepemimpinan dan iklim organisasi yang tepat.

Demikian pula yang terjadi di lingkungan kinerja pegawai pada dinas pemuda olahraga kebudayaan dan pariwisata, dimana kurangnya informasi dan sosialisasi terhadap ketentuan dan peraturan sehingga sering terjadi kesimpangsiuran dalam penyelesaian pekerjaan yang diinstruksikan pemimpin. Adanya pergantian pemimpin akan berdampak pada kondisi kerja sehingga menimbulkan perubahan perilaku kerja yang dibawa oleh pemimpin yang baru yang berdampak pula pada kinerja karyawan.

Melihat betapa pentingnya seorang pemimpin dalam kegiatan instansi dan hubungannya terhadap bawahannya dalam kecakapan tujuan instansi maka perlu dilakukan penelitian. Penelitian ini bertujuan untuk menganalisis pengaruh iklim organisasi terhadap kinerja karyawan, pengaruh gaya kepemimpinan terhadap kinerja karyawan, pengaruh iklim organisasi dan gaya kepemimpinan terhadap kinerja karyawan pada kantor dinas pemuda olahraga kebudayaan dan pariwisata di Kabupaten Hulu Sungai Tengah.

\section{TINJAUAN PUSTAKA}

\section{Kinerja Karyawan}

Kinerja dapat diartikan sebagai gambaran mengenai tingkat pencapaian pelaksanaan suatu kegiatan atau program atau kebijakan dalam mewujudkan sasaran ,tujuan, misi dan visi organisasi yang tertuang dalam rencana strategi suatu organisasi. Menurut Dessler ( 1997 ) kinerja merupakan prosedur yang meliputi :1. Penetapan standar kinerja. 2. Penilaian kinerja actual pegawai dalam hubungan dengan standarstandar ini. 3. Member umpan balik kepada pegwai dengan tujuan memotivasi orang tersebut untuk menghilangkan kemerosotan kenerja atau terus berkinerja lebih tinggi lagi. 


\section{Iklim Organisasi}

Iklim organisasi dalam suatu organisasi mempunyai peranan penting karena iklim yang serasi atau kondusif akan dapat mendorong peningkatan kualitas kinerja dan sebaliknya iklim yang bertentangan dengan kebutuhan anggota akan berimplikasi pada rendahnya kualitas kerja (1985). Berbicara mengenai iklim organisasi berarti berbicara mengenai sifat atau ciri yang dirasakan dalam lingkungan kerja dan timbul karena adanya kegiatan organisasi yang dilakukan secara sadar atau yang dianggap mempengaruhi perilaku kemudian, dengan perkataan lain iklim organisasi dapat dipandang sebagai kepribadian organisasi seperti yang terlihat oleh para anggota. Pembahasan pada konsep karakteristik lingkungan (iklim) sebenarnya, berarti membahas mengenai sifat- sifat organisasi atau ciri- ciri yang melekat dan dirasakan dalam lingkungan kerja organisasi yang timbul karena kegiatan organisasi yang dianggap mempengaruhi terhadap perilaku pegawai.

\section{Gaya Kepemimpian (leadership)}

Didefinisikan beragam oleh para ahli namun secara umum kepemimpinan menggambarkan hubungan antara pemimpin (leader) dengan yang dipimpin ( follower) (Locander et al 2002). Locander et al (2002) lebih lanjut menjelaskan bahwa kepemimpinan mengandung makna pemimpin mempengaruhi yang dipimpin tapi hubungan antara pemimpin dengan yang dipimpin bersifat saling menguntungkan kedua belah pihak. Lok dan Crawford (2001) memandang kepemimpinan sebagai sebuah proses mempengaruhi aktivitas suatu organisasi dalam upaya menetapkan dan mencapai tujuan. Sejalan dengan uraian diatas, Andrews dan Field (1998) menyimpulkan tiga elemen penting yang harus ada dalam kepemimpinan yaitu : pemimpin, yang dipimpin, dan interaksi antara keduanya. Tanpa ketiga elemen penting tersebut maka 
kepemimpinan tidak akan pernah ada.

\section{METODE PENELITIAN}

Jenis penelitian yang digunakan adalah explanatory research yaitu jenis penelitian yang menjelaskan hubungan antara variabel melalui pengujian hipotesis (Singarimbun dan Effendi, 1989).

Populasi adalah keseluruhan unit yang masuk dalam satu kesatuan,(Singa rimbun 2003) dan yang dijadikan populasi dalam penelitian ini adalah seluruh pegawai ,dan pimpinan Dinas Pemuda Olahraga Kebudayaan dan Pariwisata di Kabupaten Hulu Sungai Tengah., pimpinan yang jumlah pegawai adalah 60 orang. Seluruh populasi dijadikan responden sehingga penelitian ini adalah penelitian survey.

\section{Analisis regresi Berganda}

Setelah asumsi- asumsi klasik dapat dipenuhi maka tahap selanjutnya adalah menganalisis data dan menguji hipotesishipotesis yang diajukan dalam penelitian ini dengan menggunakan analisis regresi berganda dengan variabel moderating dengan uji interaksi. Uji interaksi atau disebut juga dengan moderate regression analysis ( MRA) merupakan aplikasi khusus regresi linier berganda dimana dalam persamaan regresinya mengandung unsure interaksi (perkalian atau dua lebih variabel independent) (Ghozali 2003). Regresi dengan interaksi umumnya menimbulkan terjadinya multikolinieritas, oleh karena itu untung mengurangi problem multikolinieritas dalam penelitian ini dilakukan transformasi dengan centering procedure menggunakan nilai deviasi rata- rata variabel (Jacard et al 1990, Lau et al 1995 dalam Hartmann and Moers 2001). Variabel independen penelitian ini mencakup kepemimpinan (X1), Budaya Organisasi (X2) dan variabel moderate yaitu interaksi antara variabel kepemimpinandan budaya organisasi (X1, X2). Sedangkan variabel dependen adalah kinerja ( $Y$ ). Model regresi berganda yang 
dikembangkan pada penelitian ini dinotasikan dalam persamaan sebagai berikut :

$\mathrm{Y}=\mathrm{a}+\mathrm{b} 1 \mathrm{X} 1+\mathrm{b} 2 \mathrm{X} 2+\mathrm{b} 3 \mathrm{X} 1 * \mathrm{X} 2 \mathrm{e}$

dimana :

$\mathrm{Y}=$ variabel dependen ( kinerja

karyawan )

$\mathrm{A}=$ konstanta

B1, b2, b3 = koefisien regresi

$\mathrm{X} 1$ = iklim organisasi

$\mathrm{X} 2$ = gaya kepemimpinan

$\mathrm{X} 1 * \mathrm{X} 2=$ moderate $($ interaksi $\mathrm{X} 1$ dan

X2 )

$\mathrm{E}=$ kesalahan prediksi ( error term )

\section{Hasil Analisis Regresi}

Analisis regresi digunakan untuk meramalkan suatu variabel dependen (Y) berdasar variabel independen $(X)$ dalam suatu persamaan linier. Berdasarkan data yang diperoleh dari 50 orang responden, pembahasan hasil penelitian dilakukan antara lain dengan menggunakan analisis Regresi Linier Sederhana dan analisis Regresi Linier Berganda. Adapun perhitungan analisis regresi menggunakan bantuan program SPSS for windows versi 21.

\section{Variabel Iklim Organisasi}

Terhadap Kinerja Pegawai

Dari hasil output pada

Analisis Regresi Variabel Iklim

Organisasi Terhadap Kinerja

Pegawai, maka masing-masing

koefisien prediktor dan konstanta

sebagai berikut :

$a=-3,320$

$\beta=1,258$

Maka persamaan regresi adalah :

$\hat{Y}=a+\beta X$

$\hat{Y}=-3,20+1,258 X$

Di mana :

$X=$ Variabel Iklim Organisasi

$\hat{Y}=$ Variabel Kinerja Pegawai

Interpretasi dari persamaan regresi

di atas sebagai berikut :

1. Nilai konstanta (a) sebesar 3,320, jika nilai prediktor iklim organisasi (X) adalah nol, maka besar nilai kinerja pegawai akan sama dengan nilai konstanta yaitu $-3,320$. Hal ini menunjukkan kinerja pegawai tanpa variabel iklim organisasi adalah negatif.

2. Nilai koefisien variabel iklim organisasi $(X)$ sebesar 1,258 
menunjukkan jika variabel iklim organisasi mengalami perubahan sebesar satu satuan, maka akan mengakibatkan perubahan kinerja pegawai sebesar 1,258 satuan. Karena nilai koefisien variabel iklim organisasi positif, maka tambahan satu satuan dari variabel iklim organisasi akan mengakibatkan bertambahnya kinerja pegawai sebesar 1,258 satuan dan sebaliknya jika variabel iklim organisasi berkurang satu satuan mengakibatkan berkurangnya kinerja pegawai sebesar 1,258 satuan.

\section{Variabel Gaya Kepemimpinan}

\section{Terhadap Kinerja Pegawai}

Berdasarkan hasil output pada Analisis Regresi Variabel Gaya Kepemimpinan Terhadap Kinerja Pegawai, maka masing-masing koefisien prediktor dan konstanta sebagai berikut :

$a=-3,654$

$\beta=0,832$

Maka persamaan regresi adalah :
$\hat{\mathrm{Y}}=\mathrm{a}+\beta \mathrm{X}$

$\hat{\mathrm{Y}}=-3,654+0,832 \mathrm{X}$

Di mana :

X = Variabel Gaya Kepemimpinan

$\hat{Y}=$ Variabel Kinerja Pegawai

Interpretasi dari persamaan regresi

di atas sebagai berikut :

1. Nilai konstanta (a) sebesar 3,654, jika nilai prediktor gaya kepemimpinan $(X)$ adalah nol, maka besar nilai kinerja pegawai akan sama dengan nilai konstanta yaitu $-3,654$. Hal ini menunjukkan kinerja pegawai tanpa variabel gaya kepemimpinan adalah negatif.

2. Nilai koefisien variabel gaya kepemimpinan $(X)$ sebesar 0,832 menunjukkan jika variabel gaya kepemimpinan mengalami perubahan sebesar satu satuan, maka akan mengakibatkan perubahan kinerja pegawai sebesar 0,832 satuan. Karena nilai koefisien variabel gaya kepemimpinan positif, maka tambahan satu satuan dari variabel gaya kepemimpinan akan mengakibatkan 
bertambahnya kinerja pegawai sebesar 0,832 satuan dan sebaliknya jika variabel gaya kepemimpinan berkurang satu satuan mengakibatkan berkurangnya kinerja pegawai sebesar 0,832 satuan.

\section{Variabel Iklim Organisasi dan}

\section{Gaya Kepemimpinan Terhadap}

\section{Kinerja Pegawai}

Dari hasil output pada

Analisis Regresi Variabel Iklim Organisasi dan Gaya Kepemimpinan Terhadap Kinerja Pegawai, maka masing-masing koefisien prediktor dan konstanta sebagai berikut :

$\mathrm{a}=-4,759$

$\beta_{1}=0,829 ; \beta_{2}=0,334$

Maka persamaan regresi berganda dalam penelitian ini adalah :

$\hat{\mathrm{Y}}=\mathrm{a}+\beta_{1} \mathrm{X}_{1}+\beta_{2} \mathrm{X}_{2}$

$\hat{Y}=-4,759+0,829 X_{1}+0,334 X_{2}$

Di mana :

$$
\begin{aligned}
& \text { a }=\text { konstanta } \\
& \beta_{1}, \beta_{2}=\text { koefisien } \\
& X_{1} \quad=\text { Variabel Iklim Organisasi } \\
& X_{2} \quad=\text { Variabel Gaya } \\
& \text { Kepemimpinan }
\end{aligned}
$$

$\hat{Y} \quad=$ Variabel Kinerja Pegawai Interpretasi dari persamaan regresi berganda di atas sebagai berikut :

1. Nilai konstanta (a) sebesar 4,759, jika nilai prediktor iklim organisasi $\quad\left(X_{1}\right), \quad$ gaya kepemimpinan $\left(\mathrm{X}_{2}\right)$ adalah nol, maka besar nilai kinerja pegawai akan sama dengan nilai konstanta yaitu $-4,759$. Hal ini menunjukkan kinerja pegawai tanpa variabel iklim organisasi dan gaya kepemimpinan adalah negatif.

2. Nilai koefisien variabel iklim organisasi $\left(X_{1}\right)$ sebesar 0,829 menunjukkan jika variabel iklim organisasi mengalami perubahan sebesar satu satuan dengan asumsi variabel gaya kepemimpinan $\left(\mathrm{X}_{2}\right)$ besarnya tetap, maka akan mengakibatkan perubahan kinerja pegawai sebesar 0,829 satuan. Karena nilai koefisien variabel iklim organisasi positif, maka tambahan satu satuan dari variabel iklim organisasi akan mengakibatkan bertambahnya 
kinerja pegawai sebesar 0,829 satuan dan sebaliknya jika variabel iklim organisasi berkurang satu satuan mengakibatkan berkurangnya kinerja pegawai sebesar 0,829 satuan.

3. Nilai koefisien variabel gaya kepemimpinan $\left(\mathrm{X}_{2}\right)$ sebesar 0,334 menunjukkan jika variabel gaya kepemimpinan mengalami perubahan sebesar satu satuan dengan asumsi variabel iklim organisasi $\left(X_{1}\right)$ besarnya tetap, maka akan mengakibatkan perubahan kinerja pegawai sebesar 0,334 satuan. Karena nilai koefisien variabel gaya kepemimpinan positif, maka tambahan satu satuan dari variabel gaya kepemimpinan akan mengakibatkan bertambahnya kinerja pegawai sebesar 0,334 satuan dan sebaliknya jika variabel gaya kepemimpinan berkurang satu satuan mengakibatkan berkurangnya kinerja pegawai sebesar 0,334 satuan.

\section{Pengujian Hipotesis}

Berdasarkan hasil perhitungan komputer program SPSS dengan memperhatikan besarnya koefisien korelasi (R) sebesar 0,942, maka dapat dinyatakan bahwa hubungan antara Iklim Organisasi terhadap Kinerja Pegawai adalah sangat kuat positif. Artinya semakin ditingkatkan Iklim Organisasi, maka akan mampu meningkatkan kinerja Pegawai.

Nilai t-tabel dengan alpha 5\% dan banyaknya sampel 50 responden diperoleh nilai 1,6759. Berdasarkan hasil perhitungan didapat nilai t-hitung sebesar + 19,441 dan jika dibandingkan dengan t-tabel sebesar 1,6759 dapat dinyatakan bahwa t-hitung > t-tabel serta probabilitas sig $=0,000<0,05$, sehingga $\mathrm{H}_{0}$ ditolak dan $\mathrm{H}_{1}$ diterima. Jadi dapat dinyatakan bahwa iklim organisasi berpengaruh secara signifikan terhadap kinerja pegawai. Adapun besarnya pengaruh iklim organisasi tersebut dapat diketahui dari koefisien determinasi 
$\left(R^{2}\right)$ sebesar 0,887 yang artinya bahwa sebesar $88,7 \%$ jumlah iklim organisasi secara signifikan mempengaruhi kinerja pegawai dan sisanya sebesar $11,3 \%$ kinerja pegawai dipengaruhi oleh faktor lain.

\section{Hipotesis 2}

$\mathrm{H}_{0}$ : gaya kepemimpinan tidak berpengaruh secara signifikan terhadap kinerja pegawai.

$\mathrm{H}_{1}$ : gaya kepemimpinan berpengaruh secara signifikan terhadap kinerja pegawai.

$$
\text { Berdasarkan hasil }
$$

perhitungan komputer program SPSS dengan memperhatikan besarnya koefisien korelasi (R) sebesar + 0,911, maka dapat dinyatakan bahwa hubungan antara gaya kepemimpinan terhadap Kinerja Pegawai adalah sangat kuat positif. Artinya semakin ditingkatkan Gaya Kepemimpinan, maka akan mampu meningkatkan kinerja Pegawai.

Nilai t-tabel dengan alpha $5 \%$ dan banyaknya sampel 50 responden diperoleh nilai 1,6759.
Berdasarkan hasil perhitungan didapat nilai t-hitung sebesar + 15,282 dan jika dibandingkan dengan t-tabel sebesar 1, 6759 dapat dinyatakan bahwa t-hitung $>$ t-tabel serta probabilitas sig $=0,000<0,05$, sehingga $\mathrm{H}_{0}$ ditolak dan $\mathrm{H}_{1}$ diterima. Jadi dapat dinyatakan bahwa gaya kepemimpinan berpengaruh secara signifikan terhadap kinerja pegawai.

Adapun besarnya pengaruh gaya kepemimpinan tersebut dapat diketahui dari koefisien determinasi $\left(R^{2}\right)$ sebesar 0,830 yang artinya bahwa sebesar 83\% jumlah gaya kepemimpinan secara signifikan mempengaruhi kinerja pegawai dan sisanya sebesar $17 \%$ kinerja pegawai dipengaruhi oleh faktor lain.

\section{Hipotesis}

$\mathrm{H}_{0}$ : iklim organisasi dan gaya kepemimpinan secara bersama-sama tidak berpengaruh secara signifikan terhadap kinerja pegawai.

$\mathrm{H}_{1}$ : iklim organisasi dan gaya kepemimpinan secara bersama-sama berpengaruh secara signifikan terhadap kinerja pegawai. 
Berdasarkan hasil bahwa iklim organisasi dan gaya perhitungan komputer program kepemimpinan secara bersama-sama SPSS dengan memperhatikan besarnya koefisien korelasi (R) sebesar 0,958, maka dapat dinyatakan bahwa hubungan antara Iklim Organisasi dan Gaya Kepemimpinan secara bersamasama adalah sangat kuat positif terhadap Kinerja Pegawai. Artinya semakin ditingkatkan Iklim Organisasi dan Gaya Kepemimpinan secara bersamasama, maka akan mampu meningkatkan kinerja Pegawai.

Nilai F-tabel dengan alpha $5 \%$ dan banyaknya sampel 50 responden diperoleh nilai 3,18. Berdasarkan hasil perhitungan didapat nilai F-hitung sebesar + 263,238 dan jika dibandingkan dengan F-tabel sebesar 3,18 dapat dinyatakan bahwa F-hitung > F-tabel serta probabilitas sig $=0,000<0,05$, maka artinya pengaruh iklim organisasi dan gaya kepemimpinan secara bersama-sama sangat signifikan, sehingga $\mathrm{H}_{0}$ ditolak dan $\mathrm{H}_{1}$ diterima. Jadi dapat dinyatakan berpengaruh signifikan terhadap kinerja pegawai.

Adapun besarnya pengaruh iklim organisasi dan gaya kepemimpinan secara bersama-sama dapat diketahui dari koefisien determinasi $\left(R^{2}\right)$ sebesar 0,918 yang artinya bahwa sebesar 91,8\% iklim organisasi dan gaya kepemimpina secara bersama-sama signifikan mempengaruhi kinerja pegawai dan sisanya hanya $8,2 \%$ kinerja pegawai dipengaruhi oleh faktor lain.

\section{Pembahasan}

Berdasarkan hasil pengolahan dan analisis data yang dilakukan, ada beberapa temuan yang berhasil diungkapkan baik temuan empirik maupun temuan teoritik.

\section{Temuan Empirik}

\section{Variabel Iklim organisasi (X1)}

Variabel iklim organisasi (X1) diukur melalui 6 item indikator Yaitu : struktur tugas (X1.1), Promosi jabatan (X1.2), Sistem 
pengambilan keputusan (X1.3), Orientasi pada prestasi kerja (X1.4), Terbangunnya kerjasama (X.1.5) dan keterbukaan dalam pengelolaan organisasi (X1.6). Dari keenam item indikator tersebut item indikator yang paling besar kontribusinya dalam mencerminkan variabel iklim prganisasi adalah item Sistem pengambilan keputusan (X1.3) dengan nilai Rata rata 3,58, kemudian item Terbangunnya kerjasama (X.15) dengan nilai rerata 3,30, berikutnya keterbukaan dalam pengelolaan organisasi (X1.6) dan item struktur tugas (X1.1) dengan masing masing nilai rerata 2,92 dan 2,80 sedangan item yang berkontribusi lebih kecil dalam mencerminkan variabel iklim kerja ialah item orientasi pada prestasi kerja (X1.4), dan item promosi jabatan (X1.2) dengan masing masing nilai rerata sebesar 2,64 dan 2,02 .

\section{Variabel Gaya Kepemimpinan}

(X2)

Variabel gaya kepemimpinan

(X2) diukur melalui 2 (dua) indikator yaitu : Indikator Kepemimpinan transformasional (X2.1) dan Indikator kepemimpinan Transaksional (X.2.2). untuk Indikator Kepemimpinan transformasional (X2.1) dinilai melalui 4 item yaitu: Pemimpin memiliki kharismatik (X2.1.1), Pimpinan yang lebih inspiratif dan memiliki kemampuan untuk memotivasi bawahannya agar lebih berprestasi (X2.1.2), melakukan pengembangan intelektual bagi para bawahannya (X2.1.3), selalu memberikan perhatian kepada bawahannya (X2.1.4), dari keempat item tersebut yang berkontribusi besar terhadap mencerminan indikatot kepemimpinan transformasional $\quad(\mathrm{X} 2.1)$ adalah selalu memberikan perhatian kepada bawahannya (X2.1.4) dengan nilai rerata 3,30 dan menyusul dua item lainnya yaitu melakukan pengembangan intelektual bagi para bawahannya (X2.1.3) dan Pemimpin memiliki kharismatik dengan nilai rerata masing masing 2,80 dan 2,66 sedanglan item yang 
memberian kontribusi terendah untuk mencerminan indikator kepemimpinan transformasional (X2.1) adalah item Pimpinan yang lebih inspiratif dan memiliki kemampuan untuk memotivasi bawahannya agar lebih berprestasi (X2.1. 2) dengan nilai rerata 2,20.

\section{Berikutnya}

Indikator kepemimpinan Transaksional (X.2.2). dinilai melalui 5 item yaitu: memberikan imbalan selalu menyesuaikan dengan kinerja karyawan (X2.2.1), memberikan penghargaan selalu atas dasar prestasi kerja (X2.2.2), Pemberian sangsi/hukuman kepada karyawan yang bermasalah (X2.2.3), melakukan pengawasan secara ketat (X2.2.4), melakukan koreksi dalam pelaksanaan pekerjaan (X2.2.5), dari kelima item tersebut yang berkontribusi besar terhadap mencerminan indikatot kepemimpinan transaksional (X2.2) adalah item memberikan penghargaan selalu atas dasar prestasi kerja (X2.2.2) dan melakukan koreksi dalam pelaksanaan pekerjaan

(X2.2.5) dimana nilai rerata kedua item tersebut adalah sama yaitu 3,34 dan item berikutnya yang berkontribusi besar mencerminkan indikatot kepemimpinan transaksional (X2.2) ialah melakukan pengawasan secara ketat (X2.2.4) dengan nilai rerata 3,30 dan item yang memberikan kontribusi rendah ialah Pemberian sangsi/hukuman kepada karyawan yang bermasalah (X2.2.3), memberikan imbalan selalu menyesuaikan dengan kinerja karyawan (X2.2.1) dengan masing masing nilai rerata 2,80 dan 2,44.

Berdasarkan kedua indikator tersebut maka indikator yang memberikan kontribusi yang paling besar terhadap variabel gaya kepemimpinan ialah indikator kepemimpina transaksional dan yang paling lemah adalah kepemimpinan transformasional.

\section{Variabel Kinerja (Y1)}

Variabel kinerja (Y1) diukur melalui 2 (dua) indikator yaitu : Indikator Kedisiplinan (Y.1.1) dan Indikator hasil pekerjaan (Y.1.2). 
untuk Indikator Indikator Kedisiplinan (Y.1.1) dinilai melalui 4 item yaitu: Pegawai /karyawan datang tepat waktu (Y1.1.1), pegawai/karyawan pulang tepat waktu (Y1.1.2), karyawan yang bolos bekerja (Y1.1.3), karyawan terkena sangsi akibat melanggar aturan (Y1.1.4). Dari keempat item tersebut yang berkontribusi besar terhadap mencerminan indikator Kedisiplinan (Y.1.1) ialah item Pegawai /karyawan datang tepat waktu (Y1.1.1) dengan nilai rerata 2,32 berikutnya item karyawan terkena sangsi akibat melanggar aturan (Y1.1.4) dengan nilai rerata 2,20 sedangkan item yang berkontribusi terendah terhadap indikator kedisiplinan ialah pegawai/karyawan pulang tepat waktu (Y1.1.2), dan karyawan yang bolos bekerja (Y1.1.3), dengan nilai rerata masing masing 2,14 dan 2,12.

$$
\text { Berikutnya Indikator hasil }
$$
pekerjaan (Y.1.2) diukur melalui tiga item yaitu karyawan dapat melaksanakan pekerjaannya dengan tepat sesuai standar yang ditentukan oleh organisasi

(Y.1.2.1),

pegawai/karyawan

dapat menyelesaikan pekerjaannya tepat waktu (Y.1.2.2), dan pegawai dapat menyelesaikan pekerjaannya sesuai jumlah target yang ditentukan organisasi (Y.1.2.3). Dari ketiga item tersebut item yang memberikan kontribusi terbesar terhadap mencerminkan indikator hasil pekerjaan (Y.1.2) adalah item karyawan dapat melaksanakan pekerjaannya dengan tepat sesuai standar yang ditentukan oleh organisasi (Y.1.2.1) dengan nilai rerata 3,30 selanjutnya item pegawai dapat menyelesaikan pekerjaannya sesuai jumlah target yang ditentukan organisasi (Y.1.2.3) dengan nilai rerata 3,10 dan sedangkan item yang paling rendah mencerminkan indikator hasil pekerjaan ialah pegawai/karyawan dapat menyelesaikan pekerjaannya tepat waktu (Y.1.2.2) dengan nilai rerata 2,96.

Berdasarkan kedua indikator tersebut maka indikator yang paling tinggi kontribusinya mencerminkan 
variabel kinerja ialah indikator hasil kerja dan yang paling lemah ialah kedisiplinan.

\section{KESIMPULAN}

1. Iklim organisasi secara farsial berpengaruh signifikan terhadap kinerja pegawai

2. Gaya kepemimpinan secara farsial berpengaruh signifikan terhadap kinerja pegawai

3. Iklim organisasi dan gaya kepemimpinan secara simultan berpengaruh signifikan terhadap kinerja pegawai

Saran saran :

1. Pengambillan keputusan dengan sistem sentralistik, terciptanya hubungan kerjasama yang baik, serta keterbukaan dalam pengelolaan organisasi perlu terus dipertahankan dan dikembangkan karena ketiga indikator inilah yang memberikan kontribusi yang paling besar didalam mewarnai iklim organisasi pada Dinas Pemuda Olah Raga Kebudayaan dan Pariwisata Kabupaten Hulu Sungai Tengah
2. Struktur tugas,promosi jabatan dan prestasi kerja perlu terus dipacu agar kedepan ketiga indikator ini akan memberikan kontribusi yang besar dalam menciptakan iklim organisasi di Dinas Pemuda Olah Raga Kebudayaan Dan Pariwisata Kabupaten Hulu Sungai Tengah.

3. Perhatian yang telah diberikan kepada bawahan selama ini dan pengembangan intelektual yang dberikan kepada para bawahan selama ini perlu terus dipertahankan dan bahkan kalau bisa perlu terus ditingkatkan karena kedua indikator ini memberikan kontribusi yang paling besar dalam mewarnai gaya kepemimpinan di Dinas Pemuda Olah Raga Kebudayaan Dan Pariwisata Kabupaten Hulu Sungai Tengah.

\section{DAFTAR PUSTAKA}

Abdul Rashid, M.Z., M. Sambasivan \& J. Johari (2003), “The influence of 


$$
\begin{array}{ll}
\text { corporate } & \multicolumn{1}{c}{\text { culture and }} \\
& \begin{array}{l}
\text { organizational } \\
\text { commitment on } \\
\text { performance", }
\end{array} \\
\text { Journal Management } & \text { of } \quad \text { Development, Vol. 22, } \\
& \text { No. 8, pp. 708-728 }
\end{array}
$$

AbuAlrub, RF (2004)," Job Stress, Job Performance, and Social Support Among

Hospital Nurses", Journal of Nursing Scholarship, First Quarter.

Agarwal, S., T.E. DeCarlo \& S.B. Vyas (1999),

“Leadership behavior and organizational commitment: A comparative study of American and Indian salespersons" Journal of International Business Studies, Vol. 30, No. 4 , pp. $727-743$

Antonioni, D. (1996), “Two strategies for responding to stressors: Managing conflict and clarifying work expectations", Journal of Business and

Psychology, Vol. 11, hal. 287-295. Arnolds, C.A. \& C. Boshoff (2002), "Compensation, esteem valence and job
performance: An empirical assessement of Aldefer's ERG theory", International Journal of Human Resource Management, Vol. 113, No. 4, pp. 697-719

Babin, B.J. \& J.S. Boles (1998), “Employee behavior in a service environment: A model and test of potential differences between men and women", Journal of Marketing, Vol. 62, hal. 77-91. 
Bass, B.M., B.J. Avolio, D.I. Jung \& Y. Berson (2003), “Predicting unit

performance by assessing transformational and transactional leadership", Journal of Applied Psychology, Vol. 88, No. 2, pp. 207-218

Bolon, D.S. \& D.S. Bolon (1994), "A reconceptualization and analysis of organizational culture: The influence of groups and their idiocultures", Journal of Managerial Psychology, Vol. 9, No. 5, pp. 2227

Bono, J.E. \& T.A. Judge (2003). "Selfconcordance at work: Toward

understanding

the motivational effects of transformational leaders",

Academy of Management Journal, Vol. 46, No. 5, pp. 554-571

Cooke, R., \& Lafferty, J. (1987), “Organizational Culture Inventory. Plymouth,

MI: Human Synergistics". Journal of Management.

Douglas B. Currivan (2000), "The Causal Order Of Job Satisfaction And

Organizational Commitment In Models Of employee

Turnover", University of Massachussets, Boston, MA, USA. 